\title{
Designing a Model for Measuring Merchants' Satisfaction in E-Mall: A Mixed Method Approach
}

\author{
Shahriar Azizi (Corresponding author) \\ Faculty of Management and Accounting, Shahid Beheshti University \\ P.O. Box: 1983963113, Tehran, Iran \\ Tel: 98-21-2990-2383 E-mail: s-azizi@sbu.ac.ir
}

Jamshid Salar

Department of Management, Economics and Accounting, Payame Noor University

P.O. Box: 19395-3697, Tehran, Iran

Tel: 98-12-3226-2560 E-mail: j_salar@mpnu.ac.ir

Sara Ghabraee Langroudi

Faculty of Management and Accounting, Shahid Beheshti University

P.O. Box: 1983963113, Tehran, Iran

Tel: 98-21-2990-3136 E-mail: Ghabraei_S@mapna.com

Received: December 15, 2011

doi:10.5539/ijbm.v7n8p48
Accepted: February 15, $2012 \quad$ Published: March 16, 2012

URL: http://dx.doi.org/10.5539/ijbm.v7n8p48

\begin{abstract}
This study aims to identify effective factors on satisfaction in e-malls and evaluating merchants' satisfaction from performance of these e-malls. A sequential mixed methods research design (qual $\rightarrow$ Quan) was used in this study. In qualitative phase, two focus groups were used. In this step, conceptual and exploratory content analyses were used. Based on these analyses, authors identified 32 factors. In quantitative phase, a 39-items questionnaire was designed. Data gathered from 123 merchants of an Iranian famous e-mall. Results showed three of four main categories of merchants wants (market, contract and service) are important to merchants but the technical category is not recognized as an important factor. Results also showed that degree of importance for all categories is greater than degree of satisfaction from e-mall. This research has studied e-mall as one of the interesting and less known models in e- commerce and effective factors on satisfaction in these models.
\end{abstract}

Keywords: Electronic commerce, Electronic mall, Electronic satisfaction, B2C models, Iran

\section{Introduction}

Internet is a faster and cheaper base for consumers and businesses, but it has increased importance of customer satisfaction unprecedentedly. When shopping online, consumers usually expect the web site to support them. For example, obtaining correct and accessible information on target products and services is essential for consumers (Celik et al. 2011). Internet with accelerating and facilitating transactions has enabled the customers to rapidly shift from one site to another and form one seller to another (Cox \& Dale 2002). There are different business models in virtual business area. One of the interesting and less known models is e-mall. This model is a useful tool for improving marketing and sales power of guilds and small and family companies. In this model, company prepares a complex space for introducing and representing member's showcase and receive commissions for it. This model is very good for companies. If e-mall service provider companies aware of merchants' wants, then can service them better. Small companies and guilds have important role in employment and production, but they have financial and infrastructural limitations for good marketing. These limitations reduce their competitive power, but e-mall improves their competitive power. Also, with respect to problem of energy prices, this model helps decreasing physical traffic and elimination of creating independent sites. Also, retailer's access to guilds and suppliers with precise information improves distribution system and accessing to goods and services. The 
purpose of this research is finding important factors in e-mall in the view of merchants and evaluating their satisfaction form performance of a real e-mall.

\section{Literature Review}

\subsection{Electronic Mall}

Paul Timmers has introduced 11 internet business model that e-mall is one of them (Timmers, 1998). E-mall as said by Timmers includes a set of e-shops that act as a trade mark. E-mall is a set of shops that provided with each other and by a unique access point website. These shops joint together via common subjects such as brand, industrial activity and even pay method (Turner, 2002). Entrepreneurs starting to examine methods of using internet, reached this questions that how to attract customers. Answer to this question was difficult, because chaotic nature and unplanned form of internet madeit difficult for customers to find sellers. One solution was integrating business sites into one e-mall that was similar to physical malls in real world. The goal was that sellers pay in the form of percent of sale or in accordance with tariffs and in return mall owner take responsibility of advertising and attracting customers (Cooper \& Michael, 2005). Cooper and Michael (2005) introduced main factors of e-mall: common entrance way, voluntary membership of sellers, existence of at least one goodclass and existence of goodsfor purchasing.

\subsection{Electronic Satisfaction}

Electronic satisfaction has different definitions. In this section we introduce some of these definitions. Electronic satisfaction is defined as customer happiness from previous buying from e-business firm (Srinivasan et al. 2002). Electronic satisfaction is the degree of customer satisfaction from site design, site information or contents, ease of buying and buying security (Szymanski \& Hise, 2000). Electronic satisfaction is the degree of customer satisfaction of support for receiving and sending of goods and services, after sales services, goods and services prices, quality of website subjects, website speed, website reliability, website ease of use, security and privacy (Simms et al. 2009). Therefore, electronic satisfaction is comparing customer evaluation of expected wants (expectations) with perceived experience of internet buying (performance). Therefore, electronic satisfaction has perceptual aspect and might be different form one customer to another and even for one customer in different times. Customer expectations provide comparing basis. Customer expectations in internet business are based in four resources: customer's previous buying experience, customer's alternative buying experiences from observing others' internet buying, friends and close peoples' recommendations and company`s advertisements and promises.

\subsection{Effective Factors on Electronic Satisfaction in B2C Models}

Some researchers have done in the area of effective factors on electronic satisfaction that mainly have focused on B2C models. O'Brien (2004) believes that effective factors in e-commerce success include value, performance and services, view and feel, advertisement and promotions, personal attention, social relations, security and reliability. Chakrabortyet al. (2002) studied effective factors on B2B websites effectiveness in the view of customers. In accordance with this research result, informing, organizing, transactional mutual relation and personalization effect on websites effectiveness. Cox and Dale (2002) studied key success factors in designing and using of websites and recognized 4 factors including ease of use, customer confidence, online recourses and relational services. Cha (2011) studied the internet as a unique shopping channel to sell both real and virtual items and recognized that perceived usefulness, ease of use, enjoyment, security, social norm, flow, and gender affect intention to purchase real items through the internet.

Yang et al. (2003) surveyed effective factors on websites effectiveness from view of Singaporean customers and ranking of these factors. They identified 18 factors. Szymanski and Hise (2000) found that four factors including ease of buying, product delivery, site design and financial security effects on electronic satisfaction. Evanschitzkyet al. (2004) in a separate research examined Szymanski and Hise model among German users. In accordance with their results, ease of buying and site design were first and second factors influencing electronic satisfaction. Lee and Turban (2001) introduced effective factors on electronic satisfaction including support for receiving and sending orders, serving to customers, price, quality of website subjects, speed and ease of using websites, financial security and privacy. Mills (2002) introduced effective factors on electronic satisfaction including interaction to website, perceived quality of services and website perceived value for customers.

Wang and Huarng (2002) introduced 8 factors influencing electronic satisfaction including public feedback about website design, product competitive price, product conditions, on time delivery, product return policy, customer support, e-mail customization for customers and release activities.

A summary of these studies is showed in table 1. 
Insert Table 1- here

\subsection{Effective Factors on Merchants electronic satisfaction in e-mall}

\subsubsection{Services}

Zeithamlet al. (2002) believe that service delivery through website is fundamental strategy for success and is more important than low price and being present in internet. For delivering services in best form, management must know how customers perceive and evaluate provided services. Services in e-mall include responding to questions and problems, after sales services and support, support of sellers, training and personal communication with them.

\subsubsection{Contract}

Contract include factors such as paid cost for presenting in electronic mall, contarct extension conditions, contarct duration and discount prices. Some of electronic malls receive primal costs from sellers for being present in website and others receive some percents of sales or profit. In accordance withCooper and Michael (2005), since wide range of industries benefit from presenting in electronic malls, it is better to consider some different options for membership conditions to attract more sellers into e-mall.

\subsubsection{Market}

Different sellers in e-mall form a virtual market that has many characteristics of a physical market. Structure of mall members, existence of competitors in mall, existence of sellers from different guilds and possibility of communication with other sellers are factors that influence on e-mall success. In physical mall, buyer enters to market for finding a special product and passes from different stores and may buy the product from other seller and buys another product. Existence of some of famous brands in e-mall is one of strategies for attracting customers in e-mall (Cooper \& Michael, 2005).

\subsubsection{Privacy and Security}

Privacy and security are different concepts. Privacy is protecting personal information, not delivering them to third parties such as selling information and getting permission from people for using their information (Zeithaml et al. 2002). Privacy affects aspects such as the obtaining, distribution or the non-authorized use of personal information (Wang et al. 1998). Because e-commerce Web sites lack face-to-face relationships with consumers, they tend to collect more personal information from consumers than do brick-and-mortar retailers. As a consequence, consumers are highly concerned about their information privacy online (Cha, 1999). As well as problems with the lack of privacy, the lack of security as perceived by online consumers is another of the main obstacles to the development of e-commerce (Furnell \& Karweni, 1999). In other words, security is protecting customers from scamming and financial losses due to abuse of credit cards information or other financial information. Results show that concern for financial security has great effect on using e-commerce (Zeithaml et al. 2002). Kolsaker \& Payne (2002) maintain that security reflects perceptions regarding the reliability of the means of payment used and the mechanisms of data transmission and storage (Casaló et al. 2011).

\subsubsection{Personalization}

Personalization in a website means interaction to customer as a person, recognition of customers when return to website and preparing information accordance with customers' expressed and unexpressed preferences. In overall, personalization helps to eliminate unwanted information and products, decrease users` tries in expressing their preferences, increase search accuracy and speed of doing transactions (Chakraborty et al. 2002). Content personalization of a mall from sellers' perspective, include issues such as personal recognition and site information and content delivery in a form that more relate to them. These factors cause to increase sellers' authorities and control in managing their e-stores in e-mall.

\subsubsection{Accessibility}

Accessibility refers to ease of using a website. Low speed of download or temporary in accessibility of a website that are because of factors such as limited capacity of server or server disconnection, cause to missing sales, frustrating customers and negative advertising for website (Chakraborty et al. 2002).

In accordance with Cox and Dale (2002), speed, accessibility and search capacity effect on website quality. Customer guidance is done through links and searches (Cox \& Dale, 2002).

\subsubsection{Design}

Site design in most of researches is introduced as effect factor on website success and satisfaction. Virtual nature of website means that we must communicate with customer through text, graphic and animation. Also, customer 
guidance must be done through links and search tools. All of these factors relate to site design. If design is week, then customer can't find his desirable product and possibility of transaction will be low (Cox \& Dale, 2002).

\section{Methodology}

\subsection{Research Design and Process}

This researchis a kind of mixed research and chain model with focus on quantitative section. Mixed research is a research that gathers, analyses and combines quantitative and qualitative data in a study or set of studies. It's presumption is that using quantitative and qualitative approaches together cause to better perception of research questions (Creswell \& Clark, 2007). Chain model means that in the first step, qualitative data has gathered, then in the second step, quantitative data gathered on the basis of qualitative data. Qualitative data has gathered through focus groups and quantitative data has gathered through questionnaire.

\subsection{Population and Sample}

Population of this research is merchants that introduce their goods and services through e-mall. They include 653 merchants. These stores are a section of e-mall website and use facilities provided by mall website. Sample size of this research is 7 persons in focus group and 123 persons through questionnaire.

\subsection{Date gathering tools and method}

In this section, we introduce data gathering tools and methods. They are focus group and questionnaire.

\subsubsection{Focus group}

Focus group is a qualitative data gathering method (Basch, 1987). In order to gather qualitative data, in 2 focus group, we interviewed with 7 merchants. The objective of building focus groups was introducing effective factros on merchants' satisfaction in e-mall. In these interviews, 2 questions was asked from merchants: Why they select e-mall from other similar malls? And What are the most important factros in this mall for you?

Factors that gathered in these meetings alongside other factors that gathered from literature review, used for creating primary model.

\subsubsection{Validity and Reliability}

For gathering quantitative data, an 39-items questionnaire was designed. In each question, recognized factros in first stage (qualitative data gathering step), formed in one question. In this question, degree of importance and satisfaction of respondents from factors was asked. Questionnaire data gathering was done in 3 methods:Setting a link in page 1 of e-mall, Sending an e-mail to all of merchants, Calling to merchants.

In table 2, number of questions related to each of variables and Cronbach's Alpha isshowed.

Insert Table 2- here

\section{Results}

In this section, we show results of research in two sections: qualitative section and quantitative section.

\subsection{Qualitative Phase}

For analysing data gathered from focus group we used two methods include Coceptual Content Analysis and Exploratory Relational Content Analysis. In conceptual content analysis, were cognized indexes from surveying talks of members of focus group and coding them. Then we used Exploratory Relational Content Analysis and recognized 32 concepts in 4 groups: services, market, technical and contract. Exploratory Relational Content Analysis showed that technical group include 4 subgroup: personalization, thechnical, privacy and accessibility. These factorsare showed in table 3 .

\section{InsertTable 3- here}

\subsection{Quantitative Phase}

For analyzing quantitative data, t-test has been used. Because significant number for all factors was lower than 0.05 , therefore all factors assessed important (column 2, table 4). Also, we examined merchants` satisfaction of these factors with this test. Results showed that merchants were satisfied with factors including market, services and contract; and average satisfaction with technical factor (column 3, table 4). This test also showed that all four technical aspects of mall are important. Merchants were satisfied with accessibility and had average satisfaction with personalization, but were dissatisfied with privacy and designing.

One of the managers` preferences for improving e-mall is recognizing gap between degree of factors importance for merchants and degree of their satisfaction from mall performance. It is possible that merchants are satisfied 
from one factor, but the degree of importance they consider for that factor is greater than their satisfaction. In these conditions, despite satisfaction of merchants, e-mall managers should try to increase their satisfaction. This analyze is done through independent groups t-test. Results show that gap between importance and satisfaction of merchants in all four main factors and four subsidiary factors are significant. Importance of all of these factors is greater than degree of satisfaction of merchants' satisfaction. In other word, e-mall performance was not good enough. There are greatest negative gap respectively in technical, market, services and contract factors. Among four subsidiary factors, greatest negative gap respectively are: designing, accessibility, privacy and personalization.

\section{Insert Table 4- here}

All of numbers under $\mathrm{t}$ values column written as normal, are significant at $\mathrm{P}<0.05$ level. Italic and underlined format numbers are significant at $\mathrm{P}<0.01$ level. Purely italic numbers are insignificant.For recognizing the most important factors influencing satisfaction from e-mall, we used Friedman ANOVA test. Results show that the most important factors are respectively accessibility, services, privacy, designing, market, contract and personalization. Merchants' satisfaction priorities from 7 factors are respectively accessibility, services, market, contract, personalization, privacy and designing.

$$
\text { Insert Table 5- here }
$$

\section{Conclusion and Implications}

With respect to results of this research, services, market, contract and technical factors are influencing factors on merchants' satisfaction from e-mall. Service is the most important factor of identified factors. Because this research specially investigated influencing factors on merchants' satisfaction from e-mall, many detailed factors were identified that haven't been referred to them in previous researches. Some of these factors are unique for e-malls and some of them are in other e-commerce models. Some of special factors of e-mall are existence of many classes of goods and services, existence of many merchants in same guild, rapid finding of booth in e-mall by mall search tools, , rapid finding of booth in internet by search engines, payment fee for holding a booth, contract duration, contract renewal, receiving discount if merchant put more products in booth, no limitation in number of goods provided by merchant, presence in internet such as other competitors, having a website such as competitors and possibility of setting a linkto other merchant websites.

With respect to results of this research, practical suggestions for managers are: improving quality of pictures, speed up loading e-mall site, improving coloration of e-mall, possibility of customers' membership in booth website and improving responsiveness to merchants.

The most important limitation of this research was data gathering step. With respect to results of this research, future researches can investigate influencing factors on merchants` satisfaction in e-mall in more e-malls.

\section{References}

Basch, C. E. (1987). Focus Group Interview: An Underutilized Research Technique for Improving Theory and Practice in Health Education. Health Education Quarterly, 14(4), 411-448. http://dx.doi.org/10.1177/109019818701400404

Casaló, L., Carlos, F., \& Guinalíu, M. (2011). The Generation of Trust in the Online Services and Product Distribution: The case of Spanish Electronic Commerce. Journal of Electronic Commerce Research, 12(3), 199-213. http://dx.doi.org/ 10.1177/109019818701400404

Çelik, H. E., \& Veysel, Y. (2011). Extending the Technology Acceptance Model for adoption of E-Shopping by Consumers in Turkey. Journal of Electronic Commerce Research, 12(2), 152-164.

Cha, J. (2011). Exploring the Internet as a Unique Shopping Channel to Sell both Real and Virtual Items: A Comparison of Factors Affecting Purchase Intention and Consumer Characteristics. Journal of Electronic Commerce Research, 12(2), 115-132.

Chakraborty, G., Lala, V., \& Warren, D. (2002). An Investigation of Antecedents of B2B Websites' Effectiveness. Journal of Interactive Marketing, 16(4), 51-72. http://dx.doi.org/10.1002/dir.10044

Cooper, R., \& Michael, K. (2005). The Structure and Components of E-Mall Business Models. Collaborative Electronic Commerce Technology and research LatAm (CollECTeRLatAm 2005). University of Talca, Chile, $1-15$.

Cox, J., \& Dale, B. J. (2002). Key Quality Factors in Website Design and Use: An Examination. International Journal of Quality and Reliability Management, 19(7), 862-888. http://dx.doi.org/10.1108/02656710210434784 
Creswell, J. W., \& Plano Clark, V. L. (2007). Designing and Conducting Mixed Methods Research. Sage: Thousand Oaks, CA.

Evanschitzky, H., Iyer, G. R., Hesse, J., \& Ahlert, D. (2004). E-Satisfaction: A Re-examination. Journal of Retailing, 80 (3), 239-247. http://dx.doi.org/10.1016/j.jretai.2004.08.002

Furnell, S., \& Karweni, T. (1999). Security Implications of Electronic Commerce. A Survey of Consumers and Business. Electronic Networking Applications and Policy, 9(5), 372-382. http://dx.doi.org/10.1108/10662249910297778

Kolsaker, A., \& Payne, C. (2002). Engendering Trust in e-Commerce: A Study of Gender-based Concerns. Marketing Intelligence and Planning, 20(4), 206-214. http://dx.doi.org/10.1108/02634500210431595

Lee, M. K. O., \& Turban, E. (2001). A Trust Model for Consumer Internet Shopping. International Journal of Electronic Commerce, 6(1), 75-91.

O’Brien, J. A. (2004). Management Information Systems. McGrawHill: Irwine.

Srinivasan, S. S., Anderson, R., \& Ponnavolu, K. (2002). Customer Loyalty in E-Commerce: An Exploration of Its Antecedents and Consequences. Journal of Retailing, 78(1), 41-50. http://dx.doi.org/10.1016/S0022-4359(01)00065-3

Szymanski, D., \& Hise, R. (1998). E-satisfaction: An initial examination. Journal of Retailing, 76(3), 309-322. http://dx.doi.org/10.1016/S0022-4359(00)00035-X

Timmers, P. (1998). Business Models for Electronic Markets. Research Note, 98-21.

Turner, C. (2002). The Information Economy. Kogan Page Limited: London. US Department of Commerce Report. [Online] Available: www.census.gov/estats

Wang, H., Lee, M., \& Wang, C. (1998). Consumer Privacy Concerns about Internet Marketing. Communications of the ACM, 41(3), 63-70. http://dx.doi.org/10.1145/272287.272299

Wang, M., \& Huarng, S. A. (2002). An Empirical Study of Internet Store Customer Post Shopping Satisfaction. Special Issues of Information Systems, 3, 632-638.

Yang, X., Ahmed, Z., Chingold, M., Boon, G. S., Mei, T. S., \& Hwa, L. L. (2003). Consumer Preferences for Website design: An Asia-Pacific Perspective. Journal of Consumer Marketing, 20(1), 10-27. http://dx.doi.org/10.1108/07363760310456928

Zeithaml, V. A., Parasuraman, A., \& Malhotra, A. (2002). Service Quality Delivery through Websites: A Critical Review of Extant Knowledge. Journal of the Academy of Marketing Science, 30(4), 362-375. http://dx.doi.org/10.1177/009207002236911

Table 1. Factors Effect Satisfaction in B2C Area

\begin{tabular}{|l|l|}
\hline EffectiveFactors & Reference \\
\hline $\begin{array}{l}\text { value, performance and services, view and feel, advertisement and promotions, } \\
\text { personal attention, social relations, security and reliability }\end{array}$ & O'Brien (2004) \\
\hline informing, organizing, transactional mutual relation and personalization & Chakraborty et al. (2002) \\
\hline ease of use, customer confidence, online resources and relational services & Cox and Dale (2002) \\
\hline ease of buying, product delivery, site design and financial security & Szymanski and Hise (2000) \\
\hline ease of buying and site design & Evanschitzky et al. (2004) \\
\hline $\begin{array}{l}\text { support for receiving and sending orders, serving to customers, price, website } \\
\text { subjects quality, speed and ease of using websites, financial security and privacy }\end{array}$ & Lee and Turban (2001) \\
\hline $\begin{array}{l}\text { interaction to website, perceived quality of services and website perceived value } \\
\text { for customers }\end{array}$ & Mills (2002) \\
\hline $\begin{array}{l}\text { public feedback about website design, product competitive price, product } \\
\text { conditions, on time delivery, product return policy, customer support, e-mail } \\
\text { customization for customers and release activities }\end{array}$ & Wang and Huarng (2002) \\
\hline
\end{tabular}


Table 2. Scales Reliability

\begin{tabular}{|c|c|c|c|c|}
\hline \multirow{2}{*}{ Variable } & \multirow{2}{*}{ Scale } & \multirow{2}{*}{$\begin{array}{c}\text { No. of } \\
\text { Items }\end{array}$} & & \multicolumn{2}{|c|}{ Cronbach's Alpha } \\
\cline { 4 - 5 } & & & Importance Questions & Satisfaction Questions \\
\hline Services & likert & 5 & $0 / 734$ & $0 / 745$ \\
\hline Contract & likert & 3 & $0 / 721$ & $0 / 767$ \\
\hline Market & likert & 7 & $0 / 729$ & $0 / 732$ \\
\hline Technical & likert & 17 & $0 / 802$ & $0 / 786$ \\
\hline
\end{tabular}

Table 3. Effective Factors for E-Mall Satisfaction

\begin{tabular}{|c|c|c|}
\hline Group & Subgroup & Indicator \\
\hline Services & - & $\begin{array}{l}\text { Informing from new technologies, providing lateral services such as } \\
\text { photography and designing by mall, company responsiveness and } \\
\text { services to problems, training about using mall and possibility of personal } \\
\text { communication with mall managers }\end{array}$ \\
\hline Contract & - & $\begin{array}{l}\text { Payment fee for booth, contract period, contract extension conditions and } \\
\text { receiving discounts for setting more products in mall }\end{array}$ \\
\hline Market & - & $\begin{array}{l}\text { Existence of many goods/ services in mall, existence of many merchants } \\
\text { from different guilds, possibility of setting of links to other sites, presence } \\
\text { in internet such as other competitors, having a website such as other } \\
\text { competitors, no limitation in number of provided goods by company and } \\
\text { possibility of communication with other competitors. }\end{array}$ \\
\hline \multirow{4}{*}{ Technical } & Privacy & $\begin{array}{l}\text { No accessibility of others to booth holder email and no accessibility of } \\
\text { others to customers information. }\end{array}$ \\
\hline & Personalization & $\begin{array}{l}\text { Possibility of assigning booth designing to merchant and possibility of } \\
\text { control of panel to merchant. }\end{array}$ \\
\hline & Accessibility & $\begin{array}{l}\text { Inexistence of problems such as mall disconnection, high possibility of } \\
\text { finding merchant's website by search engines in internet, ease of finding } \\
\text { booth in mall and speed of loading website. }\end{array}$ \\
\hline & Designing & $\begin{array}{l}\text { rapid updating of site, rapid displaying of site changes, abounding volume } \\
\text { of email box, inexistence of limitation in booth designing (no limitation in } \\
\text { number of words, columns and rows of contents), quality of graphic design } \\
\text { of website, possibility of membership of customers in booth website, } \\
\text { possibility of placing high quality pictures in mall and method of designing } \\
\text { and coloration of general sections of website. }\end{array}$ \\
\hline
\end{tabular}

Table 4. Gap Analysis between Importance and Satisfaction

\begin{tabular}{|c|c|c|c|c|c|}
\hline Factor & $\begin{array}{c}\text { t-statistics } \\
\text { (Importance) }\end{array}$ & $\begin{array}{c}\text { t-statistics } \\
\text { (Satisfaction) }\end{array}$ & $\begin{array}{c}\text { t-statistics } \\
\text { (Comparing) }\end{array}$ & Interpretation & Gap Rank \\
\hline Market & 4.919 & 35.33 & -15.9 & $\mathrm{~S}<\mathrm{I}$ & 2 \\
\hline Contract & 2.316 & 23.083 & -9.6 & $\mathrm{~S}<\mathrm{I}$ & 4 \\
\hline Services & 3.985 & 38.668 & -15.8 & $\mathrm{~S}<\mathrm{I}$ & 3 \\
\hline Privacy (Technical) & 23.152 & -1.953 & -13.5 & $\mathrm{~S}<\mathrm{I}$ & $1-3$ \\
\hline Personalization (Technical) & 58.102 & 6.362 & -7.1 & $\mathrm{~S}<\mathrm{I}$ & $1-4$ \\
\hline Accessibility (Technical) & 11.201 & 0.000 & -19 & $\mathrm{~S}<\mathrm{I}$ & $1-2$ \\
\hline Designing (Technical) & 40.157 & -2.349 & -20.3 & $\mathrm{~S}<\mathrm{I}$ & $1-1$ \\
\hline Technical (Total) & 0.361 & 42.024 & -22.6 & $\mathrm{~S}<\mathrm{I}$ & 1 \\
\hline
\end{tabular}


Table 5. Friedman ANOVA Test for Ranking Importance and Satisfaction of Factors

\begin{tabular}{|c|c|c|c|c|}
\hline \multirow{2}{*}{ Factor } & \multicolumn{2}{|c|}{ Satisfaction } & \multicolumn{2}{c|}{ Importance } \\
\cline { 2 - 5 } & Rank & Mean Rank & Rank & Mean Rank \\
\hline Market & 3 & 4.34 & 5 & 3.26 \\
\hline Contract & 4 & 4.04 & 6 & 3.06 \\
\hline Services & 2 & 4.36 & 2 & 4.51 \\
\hline Privacy & 6 & 3.27 & 3 & 4.37 \\
\hline Personalization & 5 & 3.82 & 7 & 2.67 \\
\hline Accessibility & 1 & 4.93 & 1 & 5.90 \\
\hline Designing & 7 & 3.23 & 4 & $22 / 4$ \\
\hline
\end{tabular}

